\title{
ANALISA PENGARUH FAKTOR-FAKTOR PEMBENTUK FEE IJARAH (PSAK 107) TERHADAP PORTOFOLIO RAHN EMAS DI BANK SYARIAH
}

Yanti

\author{
Program Studi Akuntansi,Fakultas Bisnin dan Ilmu Sosial \\ Universitas Buana Perjuangan Karawang \\ Email : yanti@ubpkarawang.ac.id \\ Yanti \\ Buana Perjuangan University \\ Program of Accounting Science, Faculty of Bisnis and Sosial \\ Karawang, Jawa Barat , Indonesia \\ Email : yanti@ubpkarawang.ac.id
}

\begin{abstract}
This study aims to explain the influence of the factors forming the portfolio Rahn Ijarah fee at Bank Syariah gold as an Islamic Financial Institutions that have a product based on Ijarah, and to analyze the compliance by the prevailing regulations in Indonesia, the DSN-MUI Fatwa No.27 / DSN- MUI / III / 2002 and PSAK 107, "Accounting for Ijarah". The results of this study indicate that it is basically BOPO affect the performance of the bank, which is to show whether the banks have been using all the factors of production with appropriate while the views of risk can be reduced by holding diversification is to buy various types of stocks (portofolio). It is clear that the calculation for results based not only on the amount of revenue or sales gained customers, but calculated from business profits generated customers, but investors have an interest to assess companies based on the feed back rate and prospects of investments financed by debt, the determination rental rates pawn goods not sufficiently representative to measure its impact on financial performance.Another result of this study showed that the application of the Ijarah transaction has been largely correspond to the one things arranged in such provisions, although there are some things that do not correspond with the Fatwa and PSAK. The mismatches are in recognition of the burden of maintenance performed by the tenant (musta'jir) sedangkah should have the burden of the responsibility of the lessor (mujjir).
\end{abstract}

Keyword : Fee Ijarah, PSAK 107, portofolio Rahn 


\begin{abstract}
ABSTRAK
Penelitian ini bertujuan menjelaskan pengaruh faktor-faktor pembentuk fee ijarah terhadap portofolio rahn emas pada Bank Syariah sebagai Lembaga Keuangan Syariah yang memiliki produk berdasarkan akad Ijarah, serta menganalisis kesesuaiannya berdasarkan ketentuan yang berlaku di Indonesia, yaitu Fatwa DSN-MUI No.27/DSN-MUI/III/2002 dan PSAK 107 tentang “Akuntansi Ijarah”. Hasil penelitian ini menunjukkan bahwa pada dasarnya BOPO berpengaruh terhadap kinerja bank, yaitu untuk menunjukan apakah bank telah menggunakan semua faktor produksinya dengan tepat guna sedangkan dilihat dari Resiko dapat dikurangi dengan mengadakan diversifikasi yaitu dengan membeli berbagai jenis saham (portofolio). Hal ini menjelaskan bahwa perhitungan bagi hasil tidak hanya didasarkan atas jumlah pendapatan atau penjualan yang diperoleh nasabah, namun dihitung dari keuntungan usaha yang dihasilkan nasabah, akan tetapi investor memiliki ketertarikan untuk menilai perusahaan berdasarkan feed back rate dan prospek investasi yang dibiayai oleh hutang, maka penentuan tarif sewa barang gadai tidak cukup mewakili untuk mengukur pengaruhnya terhadap kinerja keuangan.Hasil lain dari penelitian ini menunjukan bahwa penerapan transaksi Ijarah tersebut sebagian besar telah sesuai dengan hal-halyang diatur dalam ketentuan tersebut, walaupun ada beberapa hal yang tidak sesuai dengan Fatwa dan PSAK. Ketidaksesuaian tersebut berada pada pengakuan beban pemeliharaan yang dilakukan oleh penyewa (musta'jir) sedangkah seharusnya beban tersebut merupakan tanggung jawab pemberi sewa (mujjir).
\end{abstract}

Kata kunci : Fee Ijarah, PSAK 107,Portofolio Rahn

\title{
1. PENDAHULUAN
}

Belakangan ini Bank Syariah menjadi fenomena di dunia financial dan perbankan. Dengan menganut sistem bagi hasil (Profit/loss sharing)yang berbeda dari bank konvensional, bank syariah turut disebut-sebut sebagai jawaban atas buruknya 
sistem perbankan di Indonesia, banyak fakar berpendapat bahwa perbankan syariah memiliki karakteristik less heat, sehingga system perbankan syariah ini tahan dalam menghadapi krisis, system perbankan konvensional dan berbagai instrument keuangannya dianggap sebagai sumber masalah dari berbagai krisis keuangan yang terjadi, seperti krisis financial subprime crisis di amerika tahun 2008. Inovasi produk merupakan salah satu aspek yang turut memicu perkembangan perbankan syariah. Inovasi produk inilah yang telah memberikan kekuatan perbankan syariah untuk menuju pada suatu bisnis perbankan yang kreatif sehingga dapat memenuhi standar, selain itu melalui pembuatan produk baru maupun adaptasi dari produk perbankan yang sudah ada menjadikan perbankan syariah mampu bersaing dengan perbankan konvensional yang sudah puluhan tahun ada di Indonesia. Sejalan dengan upaya inovasi produk perbankan syariah. Bank Indonesia telah menerbitkan buku Daftar Produk Perbankan Syariah dengan jumlah produk sebanyak 29 (dua puluh Sembilan) jenis. Dalam buku tersebut terdapat 1 (satu) produk perbankan syariah yang pada dasarnya merupakan produk yang hanya bisa dipasarkan oleh perbankan syariah pada dasarnya merupakan produk yang hanya bisa dipasarkan oleh perbankan syariah saja dan tidak bisa dipasarkan oleh perbankan konvensional, nama produk itu adalah Gadai Emas Syariah. Pada umumnya, pelaksanaan gadai emas diperbankan syariah menggunakan tiga akad yaitu qard, rahn, dan ijarah, qard adalah akad yang digunakan untuk pinjaman yang diberikan kepada nasabah, rahn untuk emas yang dijadikan sebagai jaminan, dan ijarah adalah akad untuk pembayaran biaya sewa tempat dan penitipan emas yang dijadikan sebagai jaminan. Permasalahan muncul ketika imbalan pemeliharaan ini berupa presentase dari pinjamanyang diberikan, sebagaimana praktik diperbankan. Karena hal itu para ulama dewan syariah nasional sepakat tidak setuju, karena uang yang dikeluarkan gadai adalah pinjaman, sedangkan pinjaman yang mewajibkan imbalan dalam bentuk presentase merupakan kredit berbunga yang diharamkan dalam Islam. Karena itu disepakati agar upah tidak dikaitkan dengan jumlah pinjaman tetapi dengan nilai emas yang digadaikan.Berdasarkan fenomena tersebut maka peneliti, meneliti fenomena permasalahan utama yang akan dibahas dalam penelitian ini adalah Apakah terdapat pengaruh BOPO terhadap ROE dan seberapa besar 
pengaruhnya,Apakah terdapat pengaruh Resiko terhadap ROE dan seberapa besar pengaruhnya,Apakah terdapat pengaruh Tarif Sewa Barang Gadai terhadap ROE dan seberapa besar pengaruhnya. tujuan dari penelitian ini untuk mengetahui pengaruh BOPO terhadap ROE dan seberapa besar pengaruhnya,untuk mengetahui pengaruh Resiko terhadap ROE dan seberapa besar pengaruhnya,untuk mengetahui pengaruh Tarif Sewa Barang Gadai terhadap ROE dan seberapa besar pengaruhnya.

\section{KAJIAN TEORI}

a. Ijarah

Berdasarkan PSAK 107 Ijarah adalah akad pemindahan hak guna (manfaat) atas suatu asset dalam waktu tertentu dengan pembayaran sewa (ujrah) tanpa diikuti pemindahan kepemilikan asset itu sendiri.

Menurut Salman (2012 : 270) :"Ijarah adalah akad pemindahan hak guna atas suatu barang atau jasa, dalam pembayaran upah sewa (ujrah), tanpa diikuti dengan pemindahan kepemilikan atas barang tersebut.menurut Sjahdaini (1999:70) : Ijarah berarti lease contract dan juga hire contract. Dalam kontek perbankan syariah, ijarah adalah suatu lease contract dibawah suatu bank atau lembaga keuangan menyewakan peralatan (equipment), sebuah bangunan atau barang-barang, kepada salah satu nasabahnya berdasarkan pembebanan biaya yang sudah ditentukan secara pasti sebelumnya.ijarah menurut psak 107 ada 3 jenis :Ijarah adalah akad pemindahan hak guna (manfaat) atas suatu asset atau jasa dalam waktu tertentu dengan pembayaran upah atau sewa (ujrah), tanpa diikuti dengan pemindahan kepemilikan atas asset itu sendiri.Ijarah muntanhiya bittamlik (IMBT) merupakan ijarah dengan akad (janji) dari pemberi sewa berupa perpindahan kepemilikan objek ijarah pada saat tertentu (PSAK 107). Apabila terjadi perpindahan kepemilikan maka akad dibuatkan akad yang baru dan terpisah dari akad ijarah sebelumnya secara :Hibah Penjualan sebelum akad berakhir sebesar sebanding dengan sisa cicilan sewa atau harga yang disepakati,Penjualan pada akhir masa ijarah denga pembayaran tertentu sebagai referensi yang disepakati dalam akad;Penjualan secara bertahap sebagai harga 
tertentu yang disepakati dalam akad. Jual dan sewa kembali ( sale and lease back) atau transaksi jual dan ijarah, jenis ijarah seperti ini terjadi dimana seseorang menjual asetnya kepada pihak lain dan menjual kembali asset tersebut. Transaksi jual dan sewa kembali harus merupakan transaksi yang terpisah dan tidak saling bergantung (ta'alluq) sehingga harga jual harus dilakukan pada nilai wajar dan penjualan mengakui keuntungan atau kerugian pada periode terjadinya penjualan laba rugi.

\section{b. Portofolio}

Menurut Husnan (2003:45) :"portofolio adalah sekumpulan investasi dari berbagai macam aset seperti saham, obligasi, future contract, opsi, real estate, berlian, emas, tabungan dan aset lainnya yang dimiliki seorang investor yang dimaksudkan untuk mengurangi risiko investasi dan hasil yang diharapkan.Teori portofolio pertama kali dikemukakan oleh Hary Markowitz yang mengatakan pada prinsipnya portofolio terdiri dari risk dan return, alokasi dana antara investasi yang berisiko maupun yang tidak berisiko dan penetapan portofolio yang optimal.Umumnya portofolio (investasi) dibedakan menjadi dua, yaitu pertama investasi pada aset-aset financial (financial asset) yang dilakukan di pasar uang, misalnya berupa sertifikat deposito, commercial paper, surat berharga pasar uang dan lainnya. Investasi dapat juga dilakukan di pasar modal, misalnya berupa saham, obligasi, waran, opsi, dan lain-lain. Kedua investasi pada aset-aset riil (real assets) yang berupa pembelian aset produktif, pendirian pabrik, pembukaan pertambangan, pembukaan perkebunan dan lainnya.

Didalam setiap kegiatan investasi, terkandung dua unsur pokok yangn berbanding lurus, yaitu tingkat keuntungan (return) dan risiko (risk). Semakin tinggi return yang diharapkan, maka semakin tinggi pula tingkat risiko yang harus ditanggung.Tingkat keuntungan (return) merupakan salah satu faktor penting bagi parainvestor dalam pengambilan keputusan investasi. Sundjaja dan Barlian (2002;47) mendefinisikan Return (pengembalian) adalah total keuntungan atau kerugian yang dialami pemilik modal/investor dalam suatu periode tertentu.Tingkat keuntungan (return) dari investasi dapat dinilai dengan menggunakan metode Accounting Rate of Return (ARR) atau disebut juga sebagai 
Return on Equity (ROE). Metode ini, menurut Agus Sartono (2001;143), "menggunakan dasar laba akuntansi, sehingga angka yang dipergunakan adalah laba setelah pajak (Earning After Taxes/EAT) yang dibandingkan dengan modal.tingkat keuntungan (return) yang diperoleh dari investasi juga dapat dihitung dengan menggunakan Return on Total Assets (ROA), Return On Investment (ROI) dan Return On Equity (ROE). Return on Equity (ROE) adalah ukuran keseluruhan keefektifan manajemen dalam menghasilkan laba dengan modal yang tersedia. Semakin tinggi nilai rasio ini berarti return yang dihasilkan semakin baik.

c. Rahn

Menurut Imam Taqiyyudin Abu Bakar Al-Husaini Dalam Kitabnya Kifayatul Ahyar Fii Halli Ghayati Al-Iktisar definisi Rahn Adalah akad/perjanjian utang piutang dengan menjadikan harta sebagai kepercayaan/ penguat utang dan yang memeberi pinjaman berhak menjual barang yang digadaikan itu pada saat menggadaikannya.Menurut Friantoko Rahn adalah suatu hak yang diperoleh seseorang yang berpiutang atas suatu barang bergerak, yang diserahkan padanya oleh seseorang atau oleh orang lain atas namanya, dan yang memberikan kekuasaan kepada orang berpiutang itu untuk mengambil pelunasan dari barang tersebut didahulukan daripada orang-orang yang berpiutang lainnya dengan pengecualian biaya untuk melelang barang tersebut dan biaya yang telah dikeluarkan untuk menyelamatkanya setelah barang itu digadaikan.Menurut Syafi'I Antonio Ar-rahn adalah : menahan salah satu harta milik si peminjam sebagai jaminan atas pinjaman yang diterimanya, dan barang tersebut memiliki nilai ekonomis.Dari beberapa defnisi diatas dapat diartikan bahwa rahn adalah menjamin utang dengan sesuatu yang bisa menjadi pembayar utang tersebut atau nilainya bisa menjamin utang tersebut.

Yang menjadi Landasan hukum rahn adalah diantaranya :Ijtihad Ulama Perjanjian gadai yang diajarkan Al-Qur'an dan hadist itu dalam pengembangan selanjutnya dilakukan oleh para fuqaha dengan jalan ijtihad, dengan kesepakatan para ulama bahwa gadai diperbolehkan dan para ulama tidak pernah mempertentangkan kebolehannya, demikian juga dengan landasan hukumnya. Namun demikian perlu dilakukan pengkajian ulang yang lebih mendalam 
bagaimana seharusnya pegadaian menurut landasan hukumnya.Fatwa DSN No. 25/DSN-MUI/III/2002 Bahwa pinjamn dengan menggadaikan barang sebagai jaminan hutang dalam bentuk rahn dibolehkan dengan ketentuan yang ditetapkan.

\section{Kerangka Pemikiran}

Menurut Frianto (2012:72) menyatakan bahwa Beban Operasional Pendapatan Operasional (BOPO) adalah rasio efesiensi yang digunakan untuk mengukur kemampuan manajemen bank dalam mengendalikan biaya operasional terhadap pendapatan operasional.Menurut Lukman Dendawijaya (2005:118), “Beban Operasional Pendapatan Operasional (BOPO) adalah Rasio biaya operasional yang digunakan untuk mengukur tingkat efisiensi dan kemempuan bank dalam melakukan kegiatan operasi.Mawardi Nasrah (2008) mengungkapkan bahwa "BOPO pada dasarnya berpengaruh terhadap kinerja bank, yaitu untuk menunjukan apakah bank telah menggunakan semua faktor produksinya dengan tepat guna”, sedangkan menurut muhamad (2005:166) "BOPO pada bank syariah dalam mengeluarkan biaya dalam pemberian investasi pembiayaan merupakan salah satu bentuk mekanisme produksi bank dalam rangka menghasilkan output (pendapatan) yang paling tinggi dari suatu investasi.Menurut Frianto (2005:75) untuk menunjukan efesiensi suatu bank adalah menentukan peringkat BOPO, maka dari itu harus diketahui biaya operasional dan pendapatan operasional terlebih dahulu, peringkat perolehan BOPO terdiri dari 5 (lima) kategori, semakin kecil peringkat bank, maka semakin bagus karena bank memiliki tingkat efesiensi yang sangat baik. Kategori yang terdiri dari tingkat efesiensi yang sangat buruk yaitu diata $96 \%$ sampai sangat baik kurang dari $80 \%$. Tingkat efesiensi yang cukup baik sampai baik berkisar 80\%-95\%.Menurut Frianto (2005:72) "semakin kecil rasio ini berarti semakin efesien biaya operasional yang dikeluarkan bank yang bersangkutan sehingga kemungkinan suatu bank dalam kondisi bermasalah semakin kecil”, sedangkan menurut Lukman D (2005:118) "mengatakan semakin rendah BOPO berarti semakin efesien bank tersebut dalam mengendalikan biaya operasionalnya, dengan adanya efesiensi biaya maka keuntungan yang diperoleh bank akan semakin besar”. 


\section{Resiko}

Menurut Bashori (2008:23) resiko adalah suatu variasi dari hasil-hasil yang dapat terjadi selama periode tertentu.Menurut menurut Abbas Salim (2008:43) resiko adalah ketidaktentuan atau uncertainty yang mungkin melahirkan kerugian, Menurut Wulandari (2004) menyatakan bahwa risiko dianggap sebagai kemungkinan yang diterima lebih kecil dari keuntungan yang diharapkan. Risiko dapat dikurangi dengan mengadakan diversifikasi yaitu dengan membeli berbagai jenis saham (portofolio).Menurut Rustam (2013:66) “ada beberapa penerapan resiko yang wajib disesuaikan dengan kebijakan, tujuan, ukuran dan kompleksitas usaha serta kemampuan bank" : resiko kredit, resiko pasar, resiko likuiditas, resiko operasional, resiko hukum, resiko strategis, resiko kepatuhan, resiko reputasi, resiko imbal hasil dan resiko investasi.

\section{Tarif Sewa Barang Gadai}

Biaya ijarah atau biaya sewa yang biasa di pegadaian disebut dengan ijarah adalah biaya sewa tempat yang dikenakan oleh pihak pegadaian atas barang yang digadaikan nasabah. Biaya ijarah dapat dihitung setelah barang yang digadaikan ditaksir oleh pihak pegadaian. pihak pegadaian menetapkan biaya ijarah bukan dari jumlah pinjaman nasabah, karena yang dihitung adalah besarnya nilai harga taksiran, angka $\mathrm{Rp} 10.000$ adalah angka konstanta yang digunakan pihak pegadaian dalam menghitung ijarah, sedangkan Tarif yaitu angka Rp.73, Rp.90, dan Rp.100, adalah penentuan tarif standar yang digunakan gadai syariah.Ketentuan - ketentuan tarif ijarah sebagai pembentuk laba perusahaan pertama tarif jasa simpan dihitung dari nilai taksiran barang/ marhun bi, kedua jangka waktu gadai ditetapkan 120 hari kalender. Perhitungan tarif jasa simpan dengan kelipatan sepuluh hari dihitung sejak pinjaman rahn sampai dengan tanggal melunasi pinjaman. Satu hari dihitung sepuluh hari atau dapat dihitung menurut satuan terkecil. Menurut Susilo (1999) dalam Muhammad dan Hadi (2003: 34) pedoman penaksiran yang dikelompokkan atas dasar jenis barangnya adalah sebagai berikut:Barang kantong,Barang Gudang.

Menurut Muhammad dan Hadi (2003: 36-37), Prosedur Pelunasan Kredit Gadai sesuai dengan syarat-syarat yang telah ditentukan pada waktu pemberian pinjaman, nasabah mempunyai kewajiban untuk melakukan pelunasan uang 
pinjaman yang telah diterima. Pada dasarnya, nasabah dapat dapat melunasi kewajibannya setiap saat tanpa harusmenunggu jatuh tempo pelunasan

\section{Hipotesis}

Menurut Sugiyono (2007 : 51) "hipotesis dikembangkan dari telaah teoritis sebagai jawaban sementara dari masalah atau pernyataan penelitan yang memerlukan ujian secara empiris". Hipotesis merupakan jawaban sementara dari penelitian yang akan dilakukan.

Berdasarkan landasan teori, penelitian terdahulu dan kerangka pemikiran yang telah diuraikan, maka hipotesis yang diajukan adalah sebagai berikut :

\section{Pengaruh Beban Operasional ( BOPO ) terhadap Return On Equity (ROE)}

Biaya Operasional Pendapatan Operasional adalah rasio perbandingan antara biaya operasional dan pendapatan operasional. Rasio biaya operasional ini digunakan untukmengukur tingkat dan distribusi biaya bank dalam melakukan kegiatan operasinya. Dibawah ini beberapa teori, pendapat, dan hasil penelitian pengaruh BOPO terhadap ROE :

Penelitian yang dilakukan Lukman D Wijaya (2000:120) semakin rendah BOPO berarti semakin efesien bank tersebut dalam mengendalikan biaya operasionalnya, dengan adanya efesiensi biaya maka keuntungan yang diperoleh bank akan semakin besar,Pada penelitian yang dilakukan Sidabutar (2007) menunjukan bahwa terdapat pengaruh negatif signifikan antara BOPO terhadap ROE,Pada penelitian Andreas Dietrich (2010) menunjukan bahwa BOPO berpengaruh negatif signifikan terhadap ROE, sehingga bisa disimpulkan bank yang efesien dalam opersionalnya mampu menghasilkan ROE yang tinggi sehingga bank perlu mengambil kebijakan yang tepat dalam meminimalisir biaya-biaya operasional yang tidak perlu agar dapat meningkatkan laba,Pada penelitian Imam Gozali (2007) menunjukan bahwa CAR,BOPO dan NPL berpengaruh negatif terhadap ROE, sedangkan FDR berpengaruh signifikan positif terhadapn ROE Atas dasar inilah maka hipotesa yang ke 1 dapat diduga sebagai berikut :

Ha1 : Terdapat Pengaruh negatif antara BOPO terhadap return On Equity (ROE) pada Bank Syariah.

\section{Pengaruh Resiko terhadap Return On Equity (ROE)}


Resiko merupakan tingkat ketidakpastiaan mengenai suatu hasil yang diperkirakan atau diharapkan akan diterima. Resiko ini digunakan untuk mengukur tingkat resiko yang dihadapi oleh perusahaan perbankan.beberapa teori, pendapat dan hasil penelitian pengaruh resiko terhadap ROE :Menurut Hartono (2003:132) dalam konteks portofolio risiko dibedakan menjadi dua yaitu : risiko tida sistemik dan risiko sistemik, Pada penelitian Mabruroh (2004) mencerminkan bahwa resiko kredit, akan semakin kecil pula risiko kredit yang ditanggung pihak bank. Bank dalam memberikan kredit harus melakukan analisis terhadap kemampuan debitur untuk menbayar kembali kewajibannya, Pada penelitian Gelos (2006) dalam penelitiannya menguji pengaruh NPL terhadap tingkat profitabilitas bank dimana hasil penelitiannya menunjukan bahwa besarnya resiko kredit mempengaruhi kinerja bank,Pada penelitian Fauzan et al (2012) meneliti pengaruh tingkat risiko pembiayaan musyarakah dan pembiayaan murabahah terhadap tingkat profitabilitas syariah menyatakan bahwa risiko pembiayaan musyarakah dan risiko pembiayaan murabahah berpengaruh terhadap tingkat profitabilitas bank syariah

Ha2 : Terdapat Pengaruh antara Resiko terhadap return On Equity (ROE) pada Bank Syariah.

\section{Pengaruh Tarif Sewa Barang Gadai terhadap Return On Equity (ROE}

Tarif sewa barang gadai merupakan untuk mengukur biaya sewa yang biasa di pegadaian, biaya sewa tempat yang dikenakan oleh pihak pegadaian atas barang yang digadaikan nasabah. Biaya ijarah dapat dihitung setelah barang yang digadaikan ditaksir oleh pihak pegadaian. pihak pegadaian menetapkan biaya ijarah bukan dari jumlah pinjaman nasabah, karena yang dihitung adalah besarnya nilai harga taksiran.Pada penelitian Muklish Arifin Azis (2013) menerangkan bahwa tarif sewa berdampak pada peninggkatan omzet pegadaian,sehingga tidak mempunyai pengaruh yang signfikan terhadap Return On Equity (ROE),Pada penelitian Danny Febrian (2015) menyatakan bahwa secara parsial tarif sewa barang gadai sumber pendapatan buat pegadaian akan tetapi tidak berpengaruh terhadap Return On equity (ROE)

Ha3 : Tidak Terdapat Pengaruh antara Tarif sewa terhadap return On Equity (ROE) pada Bank Syariah . 


\section{METODE PENELITIAN}

\section{Jenis Penelitian}

Jenis penelitian yang digunakan adalah penelitian kausal yang bertujuan untuk menguji hipotesis tentang pengaruh satu atau beberapa variabel (variabel Independen) terhadap variabel lainnya (variabel dependen)

\section{Definisi dan Operasionalisasi Variabel}

Definisi dan operasional variabel dalam penelitian ini terdiri dari dua jenis variabel yaitu:

\section{Variabel Dependent}

Variabel dependen dalam penelitian ini adalah Return On Equity. Menurut Syafri (2008) menyatakan return on equity ratio adalah rasio yang menunjukan berapa besar laba bersih yang diperoleh perusahaan jika diukur dari nilai equity, sedangkan menurut Brigham (2007) return on equity adalah rasio untuk mengukur kemampuan perusahaan menghasilkan laba atas modalnya sendiri, return on equity untuk mengukur kemampuan perusahaan secara keseluruhan dalam menghasilkan suatu keuntungan dengan jumlah keseluruhan modal yang tersedia dalam suatu perusahaan, semakin tinggi rasio tersebut maka akan semakin baik keadaan suatu perusahaan.

Pengukuran tingkat pengembalian yang diharapkan dari portofolio dipergunakan rumus sebagai berikut :

$$
\mathrm{ROE}=\frac{\text { Net } \text { Profit }}{\text { Equity }}
$$

Dimana :

$\begin{array}{ll}\text { ROE } & =\text { Return On Equity } \\ \text { Net Profit } & =\text { Laba Bersih } \\ \text { Equity } & =\text { Modal }\end{array}$




\section{Variabel Independen}

\section{BOPO}

Beban Operasional Pendapatan Operasional (BOPO) yaitu perbandingan antara beban operasional dengan pendapatan operasional. Beban operasional dihitung berdasarkan penjumlahan dari total beban bunga dan total beban operasional lainnya. Pendapatan operasional adalah penjumlahan dari total pendapatan bungan dan total pendapatan operasional lainnya. Rasio ini digunakan untuk mengukur tingkat efesiensi bank dalam melakukan kegiatan operasinya (Faisol:2007). Untuk mengukur variabel BOPO rumus yang digunakan adalah :

$$
\mathrm{BOPO}=\frac{\text { Beban Operasional }}{\text { Pendapatan Operasional }} \times 100 \%
$$

\section{Resiko}

Dalam penelitian ini resiko diukur dengan rasio kredit Risk (Muhamad,2009). Menurut peraturan Bank Indonesia, salah satu resiko yang timbul akibat dari kegagalan counterparty memenuhi kewajibannya, karena berbagai sebab, debitur tidak bisa memenuhi kewajibannya sebagai pihak bank menderita kerugian dengan tidak diterimanya penerimaan yang seharusnya diterima (Mawardi 2004). Oleh karena itu untuk mengantisipasi kemungkinan resiko yang timbul maka resiko pemberian pembiayaan harus diperhitungkan. Kredit Risk merupakan perbandingan antara kredit macet dengan jumlah kredit yang disalurkan, kredit risk dalam penelitian ini diukur dengan menggunakan skala pengukuran rasio dengan data yang ada pada laporan keuangan bank syariah. Adapun formulanya adalah :

$$
\text { Credit Risk }=\frac{\text { Bad Debt }}{\text { Total Loan }} \times 100 \%
$$

Dimana :

Credit Risk $=$ Resiko Kredit 
Bad Debt = Kredit Macet

Total Loan $\quad=$ Total Pembiayaan

\section{Tarif Sewa Barang Rahn}

Biaya ijarah atau tarif sewa yang biasa di pegadaian disebut dengan ijarah adalah biaya sewa tempat yang dikenakan oleh pihak pegadaian atas barang yang digadaikan nasabah. Biaya ijarah dapat dihitung setelah barang yang digadaikan ditaksir oleh pihak pegadaian.

Menurut Heri Sudarsono (2013:189):Penetapkan Tarif Sewa bukan dari jumlah pinjaman nasabah, karena yang dihitung adalah besarnya nilai harga taksiran, angka $\mathrm{Rp} 10.000$ adalah angka konstanta yang digunakan pihak pegadaian dalam menghitung ijarah, sedangkan Tarif yaitu angka Rp.73, Rp.90, dan Rp.100, adalah penentuan tarif standar yang digunakan gadai syariah. Adapun formulanya untuk menentukan tarif sewa barang rahn adalah :

Dimana :

$$
=\quad \frac{\text { Tarif sewa }=\frac{\text { NT } \times \text { Tx W }}{\mathrm{K} \times 10}}{}
$$

Harga / nilai suatu

Taksiran

barang.

Tarif = Rp. 73 , Rp. 90, Rp. 95 adalah ketetapan tarif gadai Syariah

$\mathrm{K}=$ Konstanta ditetapkan Rp. 10.000

Jangka waktu = waktu pinjaman barang yang digadaikan dihitung persepuluh hari

\section{Pengukuran Variabel}

Berdasarkan definisi dan operasionalisasi variabel diatas, maka pengukuran variabel yang digunakan adalah data skala rasio, menurut Sunyoto (2011) "data berskala rasio adalah data yang diperoleh dengan cara pengukuran, dimana jarak dua titik pada skala sudah diketahui”. Skala rasio mencakup semua keampuhan dari skala-skala sebelumnya (skala ordinal, nominal dan interval) ditambah dengan adanya titik nol yang absolut.

\section{Populasi dan Sampel Penelitian}

Penentuan sampel akan sangat membantu dalam penelitian yang dihadapkan pada sampel yang beragam dari suatu populasi. Data yang digunakan berupa data 
sekunder periode dari tahun 2010-2014. Studi kasus pada Bank Syariah Mandiri, Bank Rakyat Indonesia Syariah, dan Bank Jabar Banten. Penelitian ini mengunakan jenis data populasi.

\section{Teknik Pengumpulan Data}

Pengumpulan data merupakan hal yang harus dilakukan dalam penelitian ini untuk memperoleh hasil yang sesuai dengan tujuan penelitian ini. Data yang digunakan dalam penelitian ini adalah data sekunder periode 2010-2014 yang bersumber dari media teknologi yaitu website nya Bank Syariah Mandiri, websitnya Bank Indonesia dan annual reportnya Bank Syariah Mandiri, annual reportnya Bank Rakyat Indonesia Syariah dan annual reportnya Bank Jabar Banten Syariah.

\section{Metode Analisis}

Dalam pengolahan data, digunakan penerapan metode kuadrat terkecil biasa (Ordinary Least Squared OLS) untuk model regresi linier berganda dengan didukung oleh analisis kuantitatif dengan menggunakan model ekonometrik untuk mendapatkan gambaran yang jelas tentang hubungan antara variabel-variabel yang digunakan dalam penelitian ini. Penulis menggunakan alat bantu ekonometrika (sofware) yaitu SPSS 20.

Dalam penelitian ini menggunakan analisis kuantitatif, yaitu dimana data yang digunakan dalam penelitian berbentuk rasio. Dalam penelitian ini menggunakan jenis kuantitatif dengan format deduktif yang dimulai dari keadaan umum menuju ke hal-hal khusus. Menurut Nachrowi (2006:9) "Pemilihan alat analisis Ordinary Least Square (OLS) ini digunakan untuk mencapai penyimpangan atau error yang minimum dengan menggunakan regresi berganda (Multiple Regression) yaitu digunakan lebih dari sebuah variabel bebas. Faktor-faktor yang memepengaruhi pembentuk fee Ijarah adalah BOPO, Resiko dan Tarif sewa barang gadai yang dinyatakan dalam fungsi :

$$
\mathrm{Y}=\mathrm{f}(\mathrm{X} 1, \mathrm{X} 2, \mathrm{X} 3)
$$


Kemudian fungsi tersebut dimasukan dalam bentuk model regresi linier berganda pada ekonomtrika sebagai berikut :

$$
\begin{array}{ll}
\mathrm{Y} & =\beta 0+\beta 1 \mathrm{X} 1+\beta 2 \mathrm{X} 2+\beta 3 \mathrm{X} 3 \\
\mathrm{ROE} & =\beta 0+\beta 1 \mathrm{BOPO}+\beta 2 \text { Resiko }+\beta 3 \text { Tarif Sewa }
\end{array}
$$

Keterangan :

$$
\begin{array}{ll}
\text { ROE } & =\text { Return On Equity } \\
\beta 0 & =\text { Konstanta } \\
\beta 1, \beta 2, \beta 3 & =\text { Koefisien regresi } \\
\text { BOPO } & =\text { Biaya Operasional Pendapatan Operasional } \\
\text { Resiko } & =\text { Resiko } \\
\text { Tarif Sewa } & =\text { Tarif Sewa }
\end{array}
$$

Nilai koefisien regresi sangat berarti sebagai dasar analisis, koefisien $\beta$ akan bernilai positif (+) jika menunjukan yang searah antara veriabel independen dengan variabel dependen. Artinya kenaikan variabel independen akan mengakibatkan kenaikan dependen, begitu pula sebaliknya jika variabel independen mengalami penurunan. Sedangkan nilai $\beta$ akan negatif (-) jika menunjukan hubungan yang berlawanan, artinya kenaikan variabel independen akan mengalami penurunan variabel dependen, demikian pula sebaliknya. Uji yang pertama dilakukan adalah uji normalitas dimana untuk melihat apakah nilai residual terdistribusi normal atau tidak, selanjutanya model persamaan yang diperoleh dari pengolahan data diupayakan tidak terjadi gejala multikolinieritas, heteroskedastatisitas dan autokorelasi. Untuk mengetahui ada tidaknya gejalagejala tersebut akan dilakukan uji terlebih dahulu dengan uji asumsi klasik, berikut ini merupakan alat untuk menguji suatu nilai residul, yaitu :

\section{Uji Asumsi Klasik}

Menurut Sunyoto (2011:131) "mengungkapkan bahwa model regresi linear berganda dapat disebut baik jika terbebas dari asumsi-asumsi klasik statistik, yaitu multikolinieritas, heteroskedastisitas, autoklerasi, dan normalitas data". 


\section{Uji Normalitas}

Uji ini bertujuan untuk mengetahui data dalam variabel yang akan digunakan dalam penelitian, data yang baik dan layak digunakan dalam penelitian adalah data yang memiliki distribusi normal. Menurut Winarno (2009:5.24) : Normalitas data dapat dilihat dengan beberapa cara diantaranya dengan uji Jarque-Bera atau Histogram Test, suatu variabel dikatakan normal jika korelogram pada gambar menunjukan bahwa residual berdistribusi normal. Menurut Gujarat (2006:67) "Asumsi normalitas gangguan Ut adalah paling penting sekali mengingat uji validitas pengaruh variabel Independen baik secara serempak (uji $F)$ maupun sendiri-sendiri (uji t) dan estimasi nilai variabel dependen mensyaratkan hal ini. Apabila asumsi ini tidak terpenuhi, maka kedua uji ini dan estimasi nilai variabel dependen adalah tidak valid untuk sampel kecil atau tertentu”

Untuk menguji dengan lebih akurat, diperlukan alat analisis dan Eviews menggunakan 2 (dua) cara, yaitu dengan Histogram dan Uji Jarque-Bera adalah uji statistik untuk mengetahui apakah data berditribusi normal, uji ini mengukur perbedaan skewness dan kurtosis data dan dibandingkan dengan apabila datanya bersifat normal, Rumus yang digunakan adalah (Winarno, 2009:5.37) :

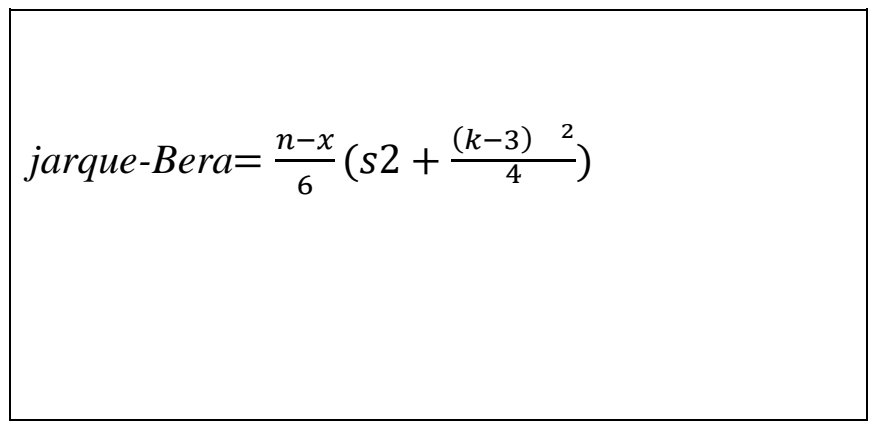

Dimana :

$\mathrm{N}=$ Ukuran Sampel

$\mathrm{S}=$ Skeness/Kemencengan

$\mathrm{K}=$ Kurtosis

$\mathrm{K}$ = Banyaknya Koefisien yang digunakan dalam persamaan 
Hipotesis:

Ho : Model tidak normal

Ha : Model Normal

Bila probabilitas Obs* $\mathrm{R}^{2}>0,05 \longrightarrow$ signifikan, Ho ditolak

Bila probabilitas Obs* $\mathrm{R}^{2}>0,05 \rightarrow$ tidak signifikan , Ho diterima.Salah satu asusmsi dalam analisis statistik adalah data berdistribusi normal. Dalam analisis multivariate, para peneliti menggunakan pedoman jika tiap variabel terdiri dari 30 data, maka data sudah berdistribusi normal, apabila melibatkab 3 variabel maka diperlukan 3x 30=90 (Ajija, 2011:42)

Jika residual tidal normal tetapi dekat dengan nilai kritis maka dapat dicoba dengan metode lain yang mungkin memberikan justifikasi normal, tetapi jika jauh dari nilai normal, maka dapat dilakukan beberapa langkah yaitu melakukan tranformasi data, melakukan triming data outliers atau menambah data observasi. Transformasi data dapa dilakukan kedalam bentuk logaritma natural, akar kuadrat, inverse, atau bentuk yang lain tergantung dari bentuk kurva normalnya, apakah condong kekiri atau ke kanan, mengumpul ke tengah atau menyebar kesamping kanan dan kiri.

\section{Uji Multikolinearitas}

Uji asumsi ini diterapkan untuk analisis regresi berganda yang terdiri atas dua atau lebih variabel bebas, dimana akan diukur tingkat asosiasi (keeratan) hubungan /berpengaruh antara veriabel bebas tersebut melalui besaran koefisien korelasi (r). dikatakan terjadi multikolinieritas, jika terjadi multikoliniearitas jika koefisien korelasi antar variabel bebas lebih kecil atau sama dengan 0,60. Variabel bebas mengalami multikolinieritas jika : $\alpha$ hitung $<\alpha$ dan VIF hitung $>$ VIF. Variabel bebas tidak mengalami multikolinieritas jika : $\alpha$ hitung $>\alpha$ dan VIF hitung $<$ VIF

\section{Uji Autokorelasi}

Persamaan regresi yang baik adalah yang tidak memiliki masalah autokorelasi, jika terjadi autokorelasi maka persamaan tersebut menjadi tidak baik/tidak layak dipakai prediksi. Masalah autokorelasi baru timbul jika ada korelasi secara linier antara kesalahan pengganggu periode $\mathrm{t}$ (berada) dengan kesalahan penggangu periode t-1(sebelumnya). Salah satu ukuran ada tidaknya masalah autokorelasi dengan uji Durbin-Watson (DW) dengan ketentuan sebagai berikut : (1) Terjadi 
autokorelasi positif, jika nilai DW dibawah -2 (DW<-2); (2) Terjadi autokorelasi positif, jika DW diantara -2 dan +2 ; dan (3) terjadi autokorelasi negatif, jika DW diatas +2 atau $\mathrm{DW}>+2$.

\section{Uji t (Uji Parsial)}

Uji t digunakan untuk menguji apakah setiap variabel bebas (Independent) secara masing-masing parsial ataun individu memiliki pengaruh yang signifikan terhadap variabel terikat (dependent) pada tingkat signifikan $0.05 \quad(5 \%)$ dengan menganggap variabel bebas bernilai konstan. Langkah-langkah yang harus dilakukan dengan uji t yaitu dengan pengujian, yaitu : (Nachrowi,2006:17)

Hipotesis:

Ho: artinya masing-masing variabel bebas tidak ada pengaruh yang signifikan dari variabel terikat Ha: artinya masing-masing variabel bebas ada pengaruh signifikan dari variabel rikat.Bila probabilitas $>\alpha 5 \%$ variabel bebas tidak signifikan atau tidak mempunyai pengaruh tarhadap variabel terikat (Ho terima, Ha tolak). Bila probabilitas $<\alpha 5 \%$ variabel bebas signifikan atau mempunyai pengaruh terhadap variabel terikat (Ho tolak, Ha terima)

\section{Uji Adj R² (Adjusted R Square)}

Menurut Ajija (2011:34) Uji koefisien determinasi koefisien $\mathrm{R}^{2}$ atau ( $\mathrm{R}^{\mathbf{2}}$ adjusted). Koefisien determinasi ini menunjukan kemampuan garis regresi menerangkan variasi variabel terikat $\mathrm{Y}$ yang dapat dijelaskan oleh variabel bebas $\mathrm{X}$, nilai koefisien $\mathrm{R}^{2}$ atau ( $\mathrm{R}^{2}$ adjusted) berkisar antara 0 sampai 1 , semakim mendekati 1 , semakin baik

\section{Uji F (Uji Fisher)}

Uji Fisher (Uji F) digunakan untuk mengetahui apakah seluruh variabel bebas (Independen) secara bersama-sama berpengaruh terhadap variabel terikat (dependen) pada tingkat signifikasi 0.05 (5\%). Pengujian semua koefisien regresi secara bersama-sama dilakukan dengan uji-F dengsn pengujian, yaitu: (Nachrowi, 2006:16)

Hipitesis: Ho : artinya secara bersama-sama tidak ada pengaruh yang signifikan antara variabel bebas terhadap variabel terikat. Ha : artinya secara bersama-sama ada pengaruh yang signifikan antara variabel bebas terhadap variabel terikat. 
Bila probabilitas $>\alpha 5 \% \rightarrow$ variabel bebas tidak signifikan atau tidak mempunyai pengaruh terhadap variabel terikat. Bila probabilitas $<\alpha 5 \%$

variabel bebas signifikan atau mempunyai pengaruh terhadap variabel terikat.

\section{HASIL DAN PEMBAHASAN}

\section{Statistik Deskriptif}

Penelitian ini menggunakan 3 sampel Bank Syariah selama 4 triwulan pada Tahun 2010-2014

a. ROE

Pada variabel ROE, hasil statistik menunjukkan nilai minimum sebesar 1.19000 yaitu Bank Rakyat Indonesia Syariah pada kuartal ke-4 tahun 2013. Hasil ini menjelaskan bahwa pada tahun 2013 modal yang dimiliki oleh Bank Rakyat Indonesia Syariah mampu menghasilkan laba sebesar 1,19\%. Nilai maksimum sebesar 74,43000 yaitu Bank Syariah Mandiri pada kuartal ke-1 tahun 2011. Hasil ini menjelaskan bahwa pada tahun 2011 modal yang dimiliki oleh Bank Syariah Mandiri mampu menghasilkan laba sebesar 74,43\%. Nilai rata-rata ROE sebesar 40,1313333. Nilai standar deviasi sebesar 23,56753142 menunjukkan variasi yang terdapat dalam variabel ROE.

\section{b. BOPO}

Pada variabel BOPO, hasil statistik menunjukkan nilai minimum sebesar 69,24000 yaitu Bank Syariah Mandiri pada kuartal ke-1 tahun 2013. Hasil ini menjelaskan bahwa pada tahun 2013 Bank Syariah Mandiri mampu melakukan efisiensi sebesar 69,24\% dalam melakukan kegiatan operasionalnya. Nilai maksimum sebesar 99,25000 yaitu Bank Rakyat Indonesia Syariah pada kuartal ke-4 tahun 2011. Hasil ini menjelaskan bahwa pada tahun 2011 Bank Rakyat Indonesia Syariah mampu melakukan efisiensi sebesar 99,25000\% dalam melakukan kegiatan operasionalnya. Nilai rata-rata BOPO sebesar 83,3926667. Nilai standar deviasi sebesar 10,01572507 menunjukkan variasi yang terdapat dalam variabel BOPO. 
c. Resiko

Pada variabel resiko, hasil statistik menunjukkan nilai minimum sebesar 0,38000 yaitu Bank Rakyat Indonesia Syariah pada kuartal ke-3 tahun 2013. Hasil ini menjelaskan bahwa perbandingan kredit macet Bank Rakyat Indonesia Syariah pada kuartal ke-3 tahun 2013 terhadap jumlah kredit yang diberikan adalah sebesar 0,38\%. Nilai maksimum sebesar 4,86 yaitu Bank Jabar Banten Syariah pada kuartal ke-1 tahun 2014. Hasil ini menjelaskan bahwa perbandingan kredit macet Bank Jabar Banten Syariah pada kuartal ke-1 tahun 2014 terhadap jumlah kredit yang diberikan adalah sebesar 4,86\%. Nilai rata-rata resiko sebesar 2,2601667. Nilai standar deviasi sebesar 1,36280181 menunjukkan variasi yang terdapat dalam variabel resiko.

\section{d. Tarif Sewa Barang Gadai}

Pada variabel tari sewa barang gadai, hasil statistik menunjukkan nilai minimum sebesar 1,35 yaitu Bank Syariah Mandiri pada kuartal ke-1 dan ke-2 tahun 2010. Hasil ini menjelaskan bahwa pada kuartal ke-1 dan ke-2 tahun 2010, Bank Syariah Mandiri memiliki tarif sewa barang gadai adalah sebesar 1,35. Nilai maksimum sebesar 1,84 yaitu Bank Syariah Mandiri pada kuartal ke-4 tahun 2014 dan Bank Rakyat Indonesia Syariah pada kuartal ke-3 tahun 2012. Hasil ini menjelaskan bahwa kedua bank tersebut memiliki tarif sewa barang gadai sebesar 1,84. Nilai rata-rata resiko sebesar 1,6100000. Nilai standar deviasi sebesar 0,13658052 menunjukkan variasi yang terdapat dalam variabel tarif sewa barang gadai..

\section{Analisa Pembahasan Hasil Penelitian}

Dalam penelitian ini proses analisis data melingkupi pengujian asumsi klasik dan pengujian hipotesis penelitian. Proses pengujian asumsi klasik dilakukan karena metode analisis yang digunakan dalam penelitian ini adalah metode regresi berganda, sedangkan pengujian hipotesis penelitian dilakukan untuk menguji ada tidaknya pengaruh suatu variabel bebas (independent variable) terhadap variabel terikat (dependent variable) secara statistik, dimana metode pengujiannya menggunakan analisis regresi berganda. 


\section{Uji Normalitas}

Dalam penelitian ini pengujian normalitas menggunakan Metode Kolmogorov Smirnov (KS). Pengujian normalitas ini dilakukan terhadap model regresi antara BOPO, resiko, tarif sewa barang gadai terhadap ROE.

Menurut metode Kolmogorov Smirnov (KS), suatu data dalam model analisis dikatakan mengikuti sebaran normal jika nilai KS hitung lebih kecil dari KS tabel atau nilai signifikansinya lebih besar dari alpha 5\%, dan sebaliknya suatu data dikatakan tidak mengikuti sebaran normal jika nilai KS hitung lebih besar dari KS tabel atau nilai signifikansinya lebih kecil dari alpha $5 \%$.

Tabel 5.1

\section{Hasil Pengujian Normalitas}

One-Sample Kolmogorov-Smirnov Test

\begin{tabular}{|ll|r|}
\hline N & $\begin{array}{r}\text { Unstandardized } \\
\text { Residual }\end{array}$ \\
Normal Parametersa,b & Mean & 60 \\
& Std. Deviation & $0 \mathrm{E}-7$ \\
& Absolute & .17 .18122218 \\
Most Extreme Differences & Positive & .074 \\
& Negative & -.102 \\
Kolmogorov-Smirnov Z & & .789 \\
Asymp. Sig. (2-tailed) & & .562 \\
\hline
\end{tabular}

a. Test distribution is Normal.

b. Calculated from data.

Sumber : Data diolah SPSS

Berdasarkan hasil pengujian normalitas residual, diketahui bahwa residual model persamaan regresi memiliki nilai Asymp. Sig 0,562 > alpha 0,05. Maka $\mathrm{H}_{0}$ diterima, artinya sebaran nilai residual pada model persamaan regresi dinyatakan berdistribusi normal. Hal ini menunjukkan bahwa model regresi, variabel dependen dan variabel independen mempunyai distribusi normal atau mendekati sehingga asumsi normalitas yang disyaratkan model terpenuhi. 
Untuk pengujian normalitas ini akan digunakan analisis Grafik Normal P-P plot dimana normalitas dapat dilihat dari penyebaran data di sekitar sumbu diagonal grafik tersebut. Jika penyebaran data berada atau menyebar disekitar garis dan mengikuti arah sumbu diagonal, maka dapat dikatakan bahwa model regresi tersebut memenuhi asumsi normalitas.

\section{Uji Asumsi Klasik}

Sebelum dilakukan pengujian regresi terlebih dahulu dilakukan pengujian pelanggaran asumsi klasik untuk model yang digunakan dalam penelitian.

\section{Uji Multikolinieritas}

Tabel 5.2

\section{Hasil Uji Multikolinieritas}

Coefficients $^{a}$

\begin{tabular}{|c|c|c|c|c|c|c|c|}
\hline \multirow[t]{2}{*}{ Model } & \multicolumn{2}{|c|}{$\begin{array}{c}\text { Unstandardized } \\
\text { Coefficients }\end{array}$} & \multirow{2}{*}{\begin{tabular}{|c}
$\begin{array}{c}\text { Standardized } \\
\text { Coefficients }\end{array}$ \\
Beta
\end{tabular}} & \multirow[t]{2}{*}{$\mathrm{t}$} & \multirow[t]{2}{*}{ Sig. } & \multicolumn{2}{|c|}{$\begin{array}{l}\text { Collinearity } \\
\text { Statistics }\end{array}$} \\
\hline & $B$ & Std. Error & & & & Tolerance & VIF \\
\hline (Constant) & .525 & .301 & & .558 & .000 & & \\
\hline BOPO & .186 & .236 & .504 & 5.017 & .000 & .941 & 1.062 \\
\hline RISK & .886 & .734 & .340 & 3.395 & .001 & .944 & 1.059 \\
\hline TARIF & -1.910 & 1.846 & -.098 & -1.004 & .320 & .996 & 1.004 \\
\hline
\end{tabular}

a. Dependent Variable: ROE

\section{Sumber : Data diolah SPSS}

Multikolinearitas menunjukkan bahwa antara variabel independen mempunyai hubungan langsung yang sangat kuat. Multikolinearitas terjadi jika nilai Variance Inflation Factor (VIF) lebih besar dari 10 atau nilai tolerance lebih kecil 0,10 .Hipotesa uji multikolinearitas $\mathrm{H}_{0} \quad$ : tidak ada multikolinearitas $\mathrm{H}_{a}$ : ada multikolinearitas Kriteria keputusan pengujian multikolinearitas:Jika VIF > 10 atau Tolerance $<0,1$ maka $\mathrm{H}_{0}$ ditolak, ada multikolinearitas Jika VIF $<10$ atau Tolerance $>0,1$ maka $\mathrm{H}_{0}$ diterima, tidak ada multikolinearitas.

diketahui bahwa seluruh variabel independen yaitu BOPO, resiko dan tarif sewa barang gadai memiliki nilai Tolerance $>0,10$ dan nilai VIF $<10$. Maka $\mathrm{H}_{0}$ diterima, artinya antar variabel independen menunjukkan tidak ada gejala multikolinearitas. Dengan kata lain, antar variabel independen pada model regresi 
pertama tidak mempunyai korelasi yang sangat kuat dengan variabel independen lainnya. Dengan demikian dapat disimpulkan bahwa model regresi yang digunakan terhindar dari permasalahan multikolinearitas.

\section{Uji Autokorelasi}

Autokorelasi menunjukkan bahwa ada korelasi antara error dengan error periode sebelumnya dimana pada asumsi klasik hal ini tidak boleh terjadi. Uji autokorelasi dilakukan dengan menggunakan Durbin Watson. Jika nilai Durbin Watson berkisar diantara nilai batas atas $\left(\mathrm{d}_{\mathrm{U}}\right)$ maka diperkirakan tidak terjadi pelanggaran autokorelasi. Dari hasil pengolahan data statistik diperoleh tabel pengujian autokorelasi sebagai berikut.

Tabel 5.3

Hasil Pengujian Autokorelasi

\begin{tabular}{|c|c|c|c|c|c|c|c|}
\hline $\mathbf{K}$ & $\mathbf{N}$ & $\mathbf{d L}$ & $\mathbf{d U}$ & $\mathbf{4 - d L}$ & $\mathbf{4 - d U}$ & $\mathbf{D W}$ & Kesimpulan \\
\hline 3 & 60 & 1,480 & 1,689 & 2,311 & 2,520 & 2,130 & Tidak Ada \\
& & & & & & & Autokorelasi \\
\hline
\end{tabular}

Dari hasil uji autokorelasi diatas diketahui bahwa model yang diteliti mempunyai jumlah obeservasi sebesar 60, dengan jumlah variabel bebas sebesar 3 variabel. Maka dapat didapat nilai batas bawah $\mathbf{d}_{\mathbf{L}}$ sebesat 1,480 dengan batas atas $\mathbf{d u}$ 1,689. Hasil uji durbin Watson didapat sebesar 2,130 berada pada daerah tidak terdapat autokorelasi.

\section{Uji Heterokedastisitas}

Dalam penelitian ini pengujian heterokedastisitas menggunakan metode glesjer. Prinsip utama dari metode glesjer ini adalah meregresikan seluruh variabel bebas (independent variable) dengan nilai residual yang sudah diabsolutkan (absolute residual). Jika terdapat hubungan yang signifikan antara variabel bebas dengan absolute residual, maka dapat dikatakan terjadi heterokedastisitas atau data tidak homogen (Ghozali. 2009: 43). 
Tabel 5.4

\section{Hasil Pengujian Heteroskedastisitas}

Coefficients $^{\mathrm{a}}$

\begin{tabular}{|c|c|c|c|c|c|c|c|}
\hline \multirow[t]{2}{*}{ Model } & \multicolumn{2}{|c|}{$\begin{array}{l}\text { Unstandardized } \\
\text { Coefficients }\end{array}$} & \multirow{2}{*}{\begin{tabular}{|c}
$\begin{array}{c}\text { Standardized } \\
\text { Coefficients }\end{array}$ \\
Beta
\end{tabular}} & \multirow[t]{2}{*}{$\mathrm{t}$} & \multirow[t]{2}{*}{ Sig. } & \multicolumn{2}{|c|}{$\begin{array}{l}\text { Collinearity } \\
\text { Statistics }\end{array}$} \\
\hline & $B$ & Std. Error & & & & Tolerance & VIF \\
\hline (Constant) & 13.266 & 18.548 & & .715 & .477 & & \\
\hline BOPO & -.028 & .136 & -.028 & -.206 & .838 & .941 & 1.062 \\
\hline RISK & .726 & .996 & .100 & .730 & .469 & .944 & 1.059 \\
\hline TARIF & .831 & 9.673 & .011 & .086 & .932 & .996 & 1.004 \\
\hline
\end{tabular}

a. Dependent Variable: abs

Sumber : Data diolah SPSS

Hasil dari uji heterokedstisitasbbahwa nilai signifikan lebih besar dari 0,05 (sig > 0,05), yang artinya bahwa Ho diterima sehingga dapat disimpulkan bahwa varians error dari model regresi homogen atau tidak ada heteroskedastisitas. Dengan demikian asumsi atas heteroskedastisitas pada model persamaan regresi telah terpenuhi. Berdasarkan uraian diatas, maka dapat disimpulkan bahwa dari 4 pengujian asumsi klasik (normalitas, multikolinieritas, autokorelasi, dan heterokedastisitas) semuanya sudah memenuhi. Sehingga pengujian hipotesis penelitian dapat dilanjutkan.

\section{Uji Hipotesis}

Dalam penelitian ini, terdapat enam hipotesis yang perlu diuji secara empiris. Semua hipotesis yang diuji tersebut adalah dugaan tentang hubungan antara variabel BOPO, resiko dan tarif sewa barang gadai terhadap ROE. Berikut adalah uraian hasil analisis data terhadap model regresi logaritma untuk menguji hipotesis yang diajukan tersebut :

\section{Uji Koefisien Determinasi (Goodness of Fit)}


Pengujian koefisien determinasi digunakan untuk menjelaskan seberapa besar variasi variabel dependen dapat dijelaskan oleh variasi variable independen. Uji koefisien determinasi diamati melalui nilai adjusted $R 2$.

Tabel 5.5

\section{Hasil Uji Koefisien Determinasi}

Model Summary ${ }^{b}$

\begin{tabular}{|l|r|r|r|r|r|}
\hline Model & \multicolumn{1}{|c|}{$\mathrm{R}$} & R Square & $\begin{array}{c}\text { Adjusted R } \\
\text { Square }\end{array}$ & $\begin{array}{c}\text { Std. Error of } \\
\text { the Estimate }\end{array}$ & $\begin{array}{c}\text { Durbin- } \\
\text { Watson }\end{array}$ \\
\hline 1 & $.684^{\mathrm{a}}$ & .469 & .440 & 17.63542971 & 2.130 \\
\hline
\end{tabular}

a. Predictors: (Constant), TARIF, RISK, BOPO

b. Dependent Variable: ROE

Sumber : Data diolah SPSS

Hasil dari pengujian R2 diketahui koefisien determinasi yang dilihat dari nilai Adj.R2 adalah 0,440. Artinya 44\% variasi dari variabel dependen ROE dapat diprediksi dari kombinasi seluruh variabel independen.

\section{Uji F (Uji Serentak)}

Dalam penelitian ini pengujian secara simultan menggunakan Uji F atau ANOVA (analysis of variance).

Tabel 5.6

\section{Hasil Uji Secara Simultan}

ANOVA $^{\mathrm{a}}$

\begin{tabular}{|c|c|c|c|c|c|}
\hline Model & $\begin{array}{l}\text { Sum of } \\
\text { Squares }\end{array}$ & $\mathrm{df}$ & $\begin{array}{l}\text { Mean } \\
\text { Square }\end{array}$ & $\mathrm{F}$ & Sig. \\
\hline $\begin{array}{l}\text { Regression } \\
\text { Residual } \\
\text { Total }\end{array}$ & $\begin{array}{l}15353.814 \\
17416.469 \\
32770.284\end{array}$ & $\begin{array}{r}3 \\
56 \\
59\end{array}$ & $\begin{array}{r}5117.938 \\
311.008\end{array}$ & 16.456 & $.000^{\mathrm{b}}$ \\
\hline
\end{tabular}

a. Dependent Variable: ROE 


\section{b. Predictors: (Constant), TARIF, RISK, BOPO}

Pengujian ini dilakukan untuk melihat pengaruh secara bersama-sama antara variabel bebas BOPO, resiko dan tarif sewa gadai barang terhadap ROE.Pengambilan keputusan uji simultan adalah sebagai berikut : Jika Sig. < alpha 0,05 maka $\mathrm{H}_{0}$ ditolak Jika Sig. > alpha 0,05 maka $\mathrm{H}_{0}$ diterima.Dari hasil uji F ini diketahui bahwa F-hitung sebesar 16,456 dengan nilai signifikansi sebesar $0.000<\alpha_{0,05}$. Maka $\mathrm{H}_{0}$ ditolak yang berarti terdapat pengaruh secara bersamasama antara seluruh variabel independen BOPO, resiko dan tarif sewa barang gadai terhadap ROE.

\section{Uji t (Uji Parsial)}

Pengujian secara parsial dimaksudkan untuk mengetahui ada tidaknya pengaruh masing-masing variabel bebas BOPO, resiko dan tarif sewa gadai barang terhadap ROE, secara individual. Pengambilan keputusan uji parsial adalah sebagai berikut : Jika sig. $<0,05$, maka $\mathrm{H}_{0}$ ditolak.Jika sig. $>0,05$, maka $\mathrm{H}_{0}$ gagal ditolak.Dalam penelitian ini pengujian parsial yang dilakukan menggunakan uji t. Berikut hasil analisis regresinya

$$
\mathrm{Y}=190,866-0,468 \text { BOPO }-0,241 \text { RISK }- \text { 0,205 TARIF + e }
$$

Tabel 5.7

\section{Uji t (Pengujian Parsial)}

\section{Coefficients $^{\mathrm{a}}$}

\begin{tabular}{|c|c|c|c|c|c|c|c|}
\hline \multirow[t]{2}{*}{ Model } & \multicolumn{2}{|c|}{$\begin{array}{l}\text { Unstandardized } \\
\text { Coefficients }\end{array}$} & \multirow{2}{*}{$\begin{array}{c}\text { Standardized } \\
\text { Coefficients }\end{array}$} & \multirow[t]{2}{*}{$t$} & \multirow[t]{2}{*}{ Sig. } & \multicolumn{2}{|c|}{$\begin{array}{l}\text { Collinearity } \\
\text { Statistics }\end{array}$} \\
\hline & $B$ & Std. Error & & & & Tolerance & VIF \\
\hline (Constant) & .525 & .301 & & .558 & .000 & & \\
\hline BOPO & .186 & .236 & .504 & 5.017 & .000 & .941 & 1.062 \\
\hline RISK & .886 & .734 & .340 & 3.395 & .001 & .944 & 1.059 \\
\hline TARIF & -1.910 & 1.846 & -.098 & -1.004 & .320 & .996 & 1.004 \\
\hline
\end{tabular}

\section{Hipotesis 1}


$\mathrm{Ho}_{1}$ : Tidak terdapat Pengaruh antara BOPO terhadap return On Equity (ROE) pada Bank Syariah

$\mathrm{Ha}_{1}$ : Terdapat Pengaruh antara BOPO terhadap return On Equity (ROE) pada Bank Syariah

Berdasarkan hasil pengujian regresi secara parsial (uji-t) yang ditunjukkan pada Tabel 5.9 terlihat bahwa nilai signifikan dari BOPO sebesar 0,000 sehingga lebih kecil dari $0,05(0,000<0,05)$. Dengan nilai koefisien sebesar 0,504 . Hasil ini menjelaskan bahwa ha diterima yang artinya terdapat pengaruh antara BOPO terhadap return on equity (ROE) pada Bank Syariah.

\section{Hipotesis 2}

$\mathrm{Ho}_{2}$ : Tidak terdapat Pengaruh antara Resiko terhadap return On Equity (ROE) pada Bank Syariah

$\mathrm{Ha}_{2}$ : Terdapat Pengaruh antara Resiko terhadap return On Equity (ROE) pada Bank Syariah

Berdasarkan hasil pengujian regresi secara parsial (uji-t) yang ditunjukkan pada Tabel 5.9 terlihat bahwa nilai signifikan dari resiko sebesar 0,001 sehingga lebih kecil dari 0,05 $(0,001<0,05)$. Dengan nilai koefisien sebesar 0,340. Hasil ini menjelaskan bahwa ha diterima yang artinya terdapat pengaruh antara resiko terhadap return on equity (ROE) pada Bank Syariah.

\section{Hipotesis 3}

Ho3: Tidak terdapat Pengaruh antara tarif sewa barang gadai terhadap return On Equity (ROE) pada Bank Syariah

Ha3: Terdapat Pengaruh antara tarif sewa barang gadai terhadap return On Equity (ROE) pada Bank Syariah

Berdasarkan hasil pengujian regresi secara parsial (uji-t) yang ditunjukkan pada Tabel 5.9 terlihat bahwa nilai signifikan dari tarif sewa barang gadai sebesar 0,320 sehingga lebih besar dari $0,05(0,320>0,05)$. Dengan nilai koefisien sebesar -0,098. Hasil ini menjelaskan bahwa ha ditolak yang artinya tidak terdapat pengaruh antara tarif sewa barang gadai terhadap return on equity (ROE) pada Bank Syariah. 


\section{Pembahasan}

Hasil dari hipotesis 1 adalah terdapat pengaruh antara BOPO terhadap return on equity (ROE) pada Bank Syariah. Hasil penelitian ini sejalan dengan penelitian yang dilakukan oleh Mawardi Nasrah (2008) yang menyatakan bahwa BOPO pada dasarnya berpengaruh terhadap kinerja bank, yaitu untuk menunjukan apakah bank telah menggunakan semua faktor produksinya dengan tepat guna. Nilai koefisien dari hipotesis 1 adalah sebesar 0,504, yang artinya adalah setiap kenaikan BOPO sebesar 1 satuan maka akan meningkatkan nilai ROE sebesar 0,504. Hasil ini menjelaskan bahwa semakin kecil rasio ini berarti semakin efesien biaya operasional yang dikeluarkan bank yang bersangkutan sehingga kemungkinan suatu bank dalam kondisi bermasalah semakin kecil, semakin rendah BOPO berarti semakin efesien bank tersebut dalam mengendalikan biaya operasionalnya, dengan adanya efesiensi biaya maka keuntungan yang diperoleh bank akan semakin besar (Lukman D, 2005:118).

Hasil dari hipotesis 2 adalah terdapat pengaruh antara resiko terhadap return on equity (ROE) pada Bank Syariah. Hasil penelitian ini sejalan dengan penelitian dari Wulandari (2004) yang menyatakan bahwa risiko dianggap sebagai kemungkinan yang diterima lebih kecil dari keuntungan yang diharapkan. Risiko dapat dikurangi dengan mengadakan diversifikasi yaitu dengan membeli berbagai jenis saham (portofolio). Hal ini menjelaskan bahwa perhitungan bagi hasil tidak hanya didasarkan atas jumlah pendapatan atau penjualan yang diperoleh nasabah, namun dihitung dari keuntungan usaha yang dihasilkan nasabah. Apabila usaha nasabah mengalami kebangkrutan, jumlah pokok pembiayaan yang diberikan bank kepada nasabah tidak akan diperoleh kembali. Inilah perbedaan dari bank konvensional dan bank syariah karena bank konvensional tidak berinvestasi pada asset berbasis ekuitas. Investor disekitar ini tentu saja menyebabkan ketidakstabilan dalam pendapatan bank syariah dan memiliki efek pada risiko likuiditas, risiko kredit, dan risiko pasar. Risiko investasi didefinisikan sebagai risiko yang muncul dari partisipasi dalam keuangan atau aktivitas bisnis lain yang disebutkan dalam menyediakan dana untuk sharing modal dalam bisnis yang 
berisiko. Bank syariah memiliki risiko investasi pada kontrak mudharabah dan musyarakah. Bank syariah menggunakan instrument ini secara substansial berpengaruh terhadap pendapatan bank, likuiditas, dan risiko lain serta volatilitas pendapatan dan modal.

Hasil dari hipotesis 3 adalah tidak terdapat pengaruh antara tarif sewa barang gadai terhadap return on equity (ROE) pada Bank Syariah. Hasil penelitian ini sejalan dengan penelitian yang dilakukan oleh Qodriasari (2014) yang menyatakan tidak terdapat pengaruh antara tarif sewa barang gadai terhadap return on equity (ROE) pada Bank Syariah. Menurut konsep signaling, bahwa investor memiliki ketertarikan untuk menilai perusahaan berdasarkan feed back rate dan prospek investasi yang dibiayai oleh hutang, maka penentuan tarif sewa barang gadai tidak cukup mewakili untuk mengukur pengaruhnya terhadap kinerja keuangan. Selain itu, komponen ROE merupakan hasil dari laba bersih setelah perusahaan membayar kewajibannya, tarif sewa barang gadai merupakan pendapatan sebelum mendapatkan laba bersih, sehingga dapat dikatakan bahwa tarif sewa barang gadai bukan merupakan faktor yang menjadi pertimbangan penentuan kinerja keuangan bank syariah.

\section{KESIMPULAN}

Berdasarkan hasil analisis data dan pembahasan yang telah dilakukan, maka dapat disimpulkan bahwa :Terdapat pengaruh antara BOPO terhadap return on equity (ROE) pada Bank Syariah. Dengan nilai signifikansi uji t sebesar 0,000 dan nilai koefisien sebesar 0,504.Terdapat pengaruh antara resiko terhadap return on equity (ROE) pada Bank Syariah. Dengan nilai signifikansi uji t sebesar 0,001 dan nilai koefisien sebesar 0,340. Tidak terdapat pengaruh antara tarif sewa barang gadai terhadap return on equity (ROE) pada Bank Syariah. Dengan nilai signifikansi uji t sebesar 0,320 dan nilai koefisien sebesar -0,098. 


\section{Daftar Pustaka}

Adisti, F. (2008). Pengaruh Pemeriksaan Operasional Atas Investasi Terhadap Efektivitas Pengelolaan Portofolio Investasi. Bandung: Universitas Widyatama.

Ahmad, K (2004). Dasar-dasar Manajemen Invetasi dan Portofolio. Jakarta: Rineka Cipta.

Azis, M.A. (2013). Analisis Pengeruh Tingkat Sewa Modal, Jumlah Nasabah, Harga Emas dan Tingkat Inflasi Terhadap Penyaluran Kredit Gadai Golongan C. Malang:Universitas Brawijaya.

Azizah. (2009). Perspektif Hukum Islam Terhadap Penerapan Prinsip Ijarah pada Praktik Tarif Jasa Simpan di Pegadaian Syariah Cabang Kusumanegara Yogyakarta. Yogyakarta: UIN.

Bank Indonesia. (2011). Statistik Perbankan Syariah Periode Desember 2010.

Bank Indonesia. (2015). Laporan Keuangan. Diakses Tanggal 13 Desember 2015 dari http.www.bi.go.id.

Bank Syariah Mandiri. (2015). Laporan Keuangan. Diakses pada 8 Desember 2015 dari http://www.syariahmandiri.co.id.

Bank Syariah Mandiri. (2015). Laporan Keuangan. Diakses pada 10 Desember 2015 dari http://www.syariahmandiri.co.id.

Bramantyo,D.P. (2006). Manajemen Resiko Korporat Terintegrasi. Jakarta: PPM.

Darmawan, D. (2013). Metode Penelitian Kuantitatif. Jakarta: Rosda.

Dendawijaya, L. (2005). Manajemen Perbankan. Jakarta: Ghalia Indonesia.

Dewan Syariah Nasional. (2000). Fatwa DSN-MUI No. 09/DSNMUI/IV/2000.

Dewan Syariah Nasional. (2002). Fatwa DSN-MUI No. 27/DSNMUI/III/2002.

Dietrich, Andreas \& Gabrielle Wanzenried. (2009). What Determines the Profitability of Commercial Banks? New Evidence from switzerland. pada tanggal 29 Desember 2012, dari website www.ssrn.com.

Fazlur, R.M. (2009). Faktor Yang Mempengaruhi Profitabilitas UUS PT. Bank X Menggunakan Rasio Keuangan. Jakarta,UI.

Fauzan, F., Arfan M., \& Darwanis. 2012. Pengaruh Tingkat Risiko Pembiayaan Musyarakah dan Pembiayaan Murabahah terhadap Tingkat Profitabilitas Bank Syariah (studi pada Bank Aceh Syariah cabang Banda Aceh). Jurnal Akuntansi, 2 (1): ISSN: 2302-0164.

Febrian, Dani. (2015). Analisis Pengaruh Tingkat Inflasi, Pendapatan Pegadaian dan Harga Emas Terhadap Penyaluran Kredit Rahn Pada pegadaian Syariah di Indonesia. Jakarta, UIN. 
Ghozali, H. Imam. 2009. Aplikasi Analisis Multivariate Dengan Program SPSS. Semarang: Badan Penerbit Universitas Diponegoro.

Gujarati, D.N. (2012). Dasar-dasar Ekonometrika, Terjemahan Mangunsong, R.C., Jakarta : Salemba Empat.

Hakim, Cecep Maskanul. (2011). Problem Pengembangan Produk Dalam Bank Syariah. Tim Penelitian dan Pengembangan Bank Syariah. DPNP: TT.

Halim,A. (2005). Analisis Investasi. Jakarta: Salemba Empat.

Hasan,U.B. (2008). Manajemen Resiko Bank Syariah. Malang: UIN.

Husnan,S. (2003). Dasar-dasar Teori Portofolio dan Analisis Sekuritas. Yogyakarta: BPPE.

Ikatan Akuntan Indonesia.(2009) Pernyataan Standar Akuntansi Keuangan No. 107-Akuntansi Ijarah. Jakarta: Salemba Empat.

Irawan,F.S. (2012). Analisis Penerapan Transaksi Ijarah Muntanhiya Bittamlik (IMBT) Berdasarkan Fatwa DSN-MUI No.27/DSN-MUI/III/2002 DAN PSAK 107 Serta Peraturan BAPEPAM-LK NO. PER-04/BL/2007. Jakarta: UI.

Jogiyanto, Hartono. (2003). Teori Portofolio dan Analisis Investasi, Edisis 2. Yogyakarta: BPFE.

Kieso, D. E., Weygandt, J.J., and Warfield T.D. (2010). Intermediate Accounting, IFRS

Edition, John Willey \& Sons: New York.

Mabruroh. (2004). Manfaat dan pengaruh Rasio Keuangan dalam Analisis Kinerja Keuangan Perbankan. Yogyakarta : Benefit.

Muhamad. (2005). Manajemen Pembiayaan Bank Syariah. Yogyakarta: UPP AMP YPKN.

Munandar, A. (2011). Analisa Akad Rahn di Perum Pegadaian Syariah CabangKusumanagara. Yogyakarta: UIN.

Nasrah, M. (2008). Faktor-faktor Yang Mempengaruhi Penetapan Return Bagi Hasil Deposito Mudharobah Muthlaqah. Jurnal Eksis Ekonomi Keuangan, 4 (1), 45-46/

Pandia, F. (2012). Manajemen Dana dan Kesehatan Bank. Jakarta:Rineka Cipta.

Remy, S.S. (1999). Perbankan Islam dan Kedudukannya Dalam Tata Hukum Perbankan Indonesia. Jakarta: Pustaka Utama Grafiti 
Riza, K.S. (2012). Akuntansi Perbankan Syariah Berbasis PSAK Syariah Padang:Akademisi.

Riyanto, B.R. (2013) Manajemen Resiko Perbankan di Indonesia. Jakarta: Salemba Empat

Salim, A. (2008). Asuransi dan Manajemen Resiko. Jakarta: Raja Grafindo Persada.

Sidabuntar, S.P. (2007). Analisis Pengaruh Kepemilikan Institusi, Net Profit Margin, Debt To Equity Ratio, Dan Rasio-Rasio Bank Terhadap Return on equity (Studi Empiris: Perusahaan perbankan Yang Listed di BEJ Periode 2003-2008 Semarang: Universitas Diponegoro

Soesilo, Zauhar.(2002). Reformasi Administrasi : Konsep, Dimensi \& Strategi, Jakarta: Aksara.

Sudarsono, H.(2015). Bank dan Lembaga Keuangan Syariah, Edisi 4 Revisi.Yogyakarta EKONISIA Kampus Fakultas Ekonomi Islam Indonesia.

Sugiyono. (2012). Metodologi Penelitian Kuantitatif Kualitatif dan $R \& D$, Alfabeta Bandung.

Sunyoto, Dadang (2011). Analisis Regresi dan Uji Hipotesis. Yoyakarta: CAPS.

Wasilah., \& Nurhayati. (2011). Akuntansi Syariah di Indonesia. Jakarta: Salemba Empat.

Wulandari, D.A. (2009). Analisis Faktor Pundamental Terhadap Harga Saham. Jurnal Akuntansi dan Keuangan.

Yusuf, Moh.(2010). Akuntansi Perbankan Syari'ah, Jakarta LPFE Usakti. 